\title{
Critical Friendship and Inter-Faculty Collaborative Inquiry: Teacher Education and Nursing Education
}

Karen Tagoonaden, Lisa Morajelo, and Lindsay Kennedy

University of British Columbia

\begin{abstract}
This paper explores how three researchers utilize critical friendship to systematically examine the nuanced roles of Teacher Education and Nursing Education practices in a community of inquiry. An ancillary theme investigates sustainable structures for supporting the professional learning of teacher and nursing educators. Respectively from two faculties on one campus, university educators came together in September 2015 to form the Critical Friendship in Nursing and Education (CFiNe) community of inquiry. Data collection includes research notes, teaching notes, journaling, and monthly meetings. This community of inquiry has the potential to provide the foundations of critically infused professional development paradigms promoting interdisciplinary and collaborative stances in higher education.
\end{abstract}

Keywords: education; caring; nursing; critical friendship; collaboration; inquiry; selfstudy

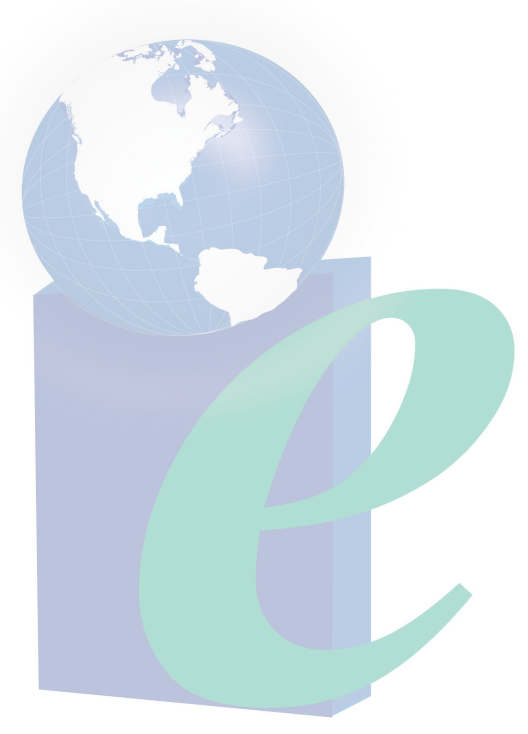




\section{Critical Friendship and Inter-Faculty Collaborative Inquiry: Teacher Education and Nursing Education}

This paper explores how three researchers use the recognized approach of critical friendship to systematically examine the nuanced roles of their own practice in a community of inquiry (Lave \& Wenger, 1991). An ancillary theme investigates sustainable structures for supporting the professional learning of teacher and nursing educators. Respectively from two professional Faculties on one campus, we came together in September 2015 to form the Critical Friendship in Nursing and Education (CFiNe) community of inquiry. Through our collaborative work, we initiated dialogue and inquiry across our respective communities while foregrounding the generative nature and value of practitioner research within and across multiple fields. We anticipate contributing to an understanding of the methodological approaches that help practitioners cultivate the knowledge, skills and dispositions that support and generate taking an inquiry stance on practice (Cochran-Smith \& Lytle, 2009 Pithouse-Morgan \& Samaras, 2015).

Within the literature on teacher inquiry and clinical judgement in nursing (Cochran-Smith \& Lytle, 2014; Jaworski, 2006; Nelson, Slavit, Perkins, \& Hathorn, 2008; Tanner, 2016), critical reflection and reflexivity emerge as important supports in the iterative cycles of examination where assumptions are challenged and confronted. In nursing education literature, Tanner (2016), acknowledges Dewey's seminal stance on reflection and critical thinking and recognizes Schön's (1983) distaste for the technical-rational model of knowledge found in most practice disciplines. Dewey (1933) states that "reflective thinking is closely related to critical thinking; it is the turning over of a subject in the mind and giving it serious and consecutive consideration" (p. 3). Dewey believed that reflection as a rational and intellectual process also involves an embodied approach to teaching and learning, considering all facets of the self in the pedagogical experience: social, emotional, physical, and intellectual. Fostering this type of an embodied reflective process is beneficial to both teacher educators and nurse educators since it nurtures the necessary conditions to support the development of self-knowledge applied as a construct to pursue professional practices. Loughran (2014) states that "this process is ultimately tied to understandings of identity; the challenges and expectations of the teacher education enterprise; and, the place of scholarship as an important marker of knowledge, skill, and ability in the academy" (p. 2).

Echoing the literature in teacher education, studies in nursing education note how expert practitioners' role modeling of reflective practice was found to significantly affect practice (Coombs, 2001; Davies, 1995; Doty, 2001; Ferry \& Ross-Gordon, 1998; Genor, 2002). Concurrently, in the area of practitioner research, Dana and Yendol-Hoppey (2014) emphasize the role educators play as knowledge-generators and refer to this self-initiated research as "teacher inquiry." This type of research focuses on the concerns of educators positioned as practitioners by engaging them in the design, data collection, and interpretation of results. Accordingly, this approach to educational research has many benefits:

- theories and knowledge are generated from research grounded in the realities of educational practice;

- teachers become collaborators in educational research by investigating their own problems; and 
- teachers play a part in the research process, which makes them more likely to facilitate change based on the knowledge they create (Dana \& Yendol-Hoppey, 2014, p. 4).

Reminiscent of Dewey $(1933 ; 1938)$ and Schön's (1983) stance on the import of reflection, an inquiry stance promotes the cultivation and nurturing of creative and critical thinking in educational contexts and, we suggest, clinical reasoning in nursing contexts. For example, clinical reasoning or clinical judgment is "the process by which nurses and other clinicians make their judgements and includes both the deliberate process of generating alternatives, weighing them against the evidence, and choosing the most appropriate, and those patterns that might be characterized as engaged, practical reasoning" (Tanner, 2016, p. 204). Similar to a teaching practice, where knowledge is grounded in reflective stances, responsive practices and ongoing collaboration, the processes related to clinical reasoning in nursing include: noticing, interpreting, responding and reflecting.

In addition to the importance of creative and critical thinking in educational contexts and of clinical reasoning in Nursing, caring is an important consideration in professional contexts such as Education and Nursing. Beck (2001) revealed themes that permeated caring in nursing education. These themes centred on reciprocal connecting that consisted of presencing, sharing, supporting, competence, and positive impact of caring. Authentic presencing sets the stage for caring to unfold. Presencing one's self centers on striving to enter the world of the other-the world of a faculty member, nursing student, or patient. Attentive listening is crucial to achieving presencing. Alongside Beck's (2001) work, professional competence surfaced in Halldorsdottir's (1990) study of caring between faculty and nursing students. Results indicated that while competence was valued, of import was the act of caring for patients and colleagues that was instrumental in setting a positive tone in the work culture. This, in turn, impacted positively on the levels of confidence and motivation of educators.

Indicative of Beck's (2001) themes of caring, Noddings (2005) refers to caring in education as the attentiveness of the one caring (or carer) for another. Since this attentiveness of caring should be receptive, in a caring relation, the cared-for recognizes the caring and responds in a positive manner. If there is no response from the cared-for, this relationship cannot be defined as a caring relation. Expanding on Dewey's (1930) virtues as "working adaptations of personal capacities with environing forces" (p. 16), Noddings (2005) accentuates reciprocity and interaction between the carer and the cared-for as a central factor in "environing forces" (p. 3). We posit that these environing forces are representative of the interconnections between the constructs of confidence, motivation, and success.

Along the same lines as Beck (2001) and Noddings (1999 2003; 2005), Bandura (1977 as cited in Lundberg, 2008) defines change within the construct of self-efficacy, as the "belief one has in being able to execute a specific task successfully" (p. 86). Consequently, the most effective way to develop self-confidence is through mastery or perceived successful experiences. Repeated successes provide individuals with solid foundations upon which to build future attempts to explore, examine, take risks, make mistakes and thus, to develop the necessary selfconfidence to progress along a pathway of one's own determination. Recognizing that optimal impact of self-confidence on the ability to think critically and creatively, and on social and emotional well-being and resilience, is an important competence to develop. Further, this type of professional knowledge mobilization serves as a platform for future iterations of communitybased professional learning dissecting across diverse disciplines, such as Education and Nursing. 


\section{Critical Friendship}

The aim of this inter-Faculty inquiry facilitated by critical friendships was to consider the necessary conditions and supports for a broad paradigm-crossing conceptual frame for professional learning, particularly as it relates to confidence, caring, and reflective practices. In teacher education and nursing education, the development of self-confidence facilitates a practice that acknowledges the importance of varied contexts and diverse perspectives. As a pathway to developing confidence, critical friends gather to address aspirations, capabilities, and challenges (Ragoonaden, 2015; Ragoonaden \& Bullock, 2016). Schuck and Russell (2005) state that "a critical friend acts as a sounding board, asks challenging questions, supports reframing of events, and joins in the professional learning experience" (p. 107). Costa and Kallick (1993) position critical friends within a paradigm where learning occurs via regular dialogue and regular feedback. In both instances, it is recognized that that since it is difficult to assess and reframe one's practice, a critical friend nurtures the emergence of alternate frames of reference upon which to introduce change. The design of an inquiry with a critical friendship might change over time to be responsive to the unique factors of the research/learning situation, especially as members discover and challenge previously held assumptions (Makaiau, Leng, \& Fukui, 2015). The purposeful application of inquiry in communities gathers momentum when participants collaboratively study the influences behind their questions and contexts and identify related or absent discourses. Within this context, the goals of this inquiry were to (a) create a responsive collective of university educators seeking to improve practice, (b) explore the role of critical friendship in Nursing and Education, and (c) disseminate and mobilize public scholarship relating to the professional development of teacher and nursing educators.

We, as critical friends, anticipated commenting on each other's practice by instigating pointed questions, by collecting data about our reflections, by analyzing the data, and by relating the collected data to relevant literature. Through this process, we anticipated renewing and revolutionizing practice based on new understandings, and by sharing and disseminating this new knowledge (Costa \& Kallick, 1993; Ragoonaden \& Bullock, 2016; Schuck \& Russell, 2005; Swaffield, 2007). A comprehensive literature review in this area indicates that the utilization of the critical friend method in various educational contexts yielded beneficial professional development outcomes for the educators involved in this process: increased confidence, confirmation of good practice, a sense of belonging to a collegial community, and breaking the sense of isolation in teaching assignments.

The term critical friend originated in the 1970s in the context of self-appraisal, attributed to Nuttall (Heller, 1988 as cited in in Gray, 1988 ). Introduced in many educational contexts, including leadership (Senge, 1990), critical friendship is utilized as a structure to elicit positive change with a focus on self-improvement of self and practice. Swaffield (2007) recognized that critical friendship, as a supportive yet challenging relationship between professionals, is being used in a variety of ways, reflective of differing contexts such as research, school improvement, and professional development. This stance, widely supported in the literature, states that established usage of critical friendship includes research with university partners and learning institutions emphasizing self-review processes leading to self-study initiatives conceptualized as ongoing professional learning. Understanding that multiple perspectives can inform sustained solutions, observation of practice can be considered as an individual internal process and reflection as an external one shared by supportive friends who challenge the status quo (West, 2000). 
In light of the above discussion, the relationship between critical friends is one that cultivates constructive critique by prompting reflection and self-appraisal. Hill (2002 in Baskerville \& Goldblatt, 2009) suggests that a critical friend encourages a scholarly inquiry approach based on a systematic approach to reframing current practice via the establishment of objectives, data collection, and reflective stances. Baskerville \& Goldblatt (2009) position reflection and discussion around shared values and beliefs as a precursor to implementing critical friendship. Along with shared narratives and discourses, trust becomes a key feature of this relationship (Costa \& Kallick, 1993; Swaffield, 2007). As individuals get to know each other, this evolves into "calculative trust" (O'Neill, 2002 as cited in Swaffield, 2007), based on weighing the evidence, and "practice trust," based on the experience of co-operative working (Bottery, 2003 as cited in Swaffield, 2007 ). Within professional contexts, trust can be contextual and related to judgements about capability commitment (Perkins, 2003 as cited in Swaffield, 2007). Swaffield (2007) aptly recognizes that competing agendas, conflicting priorities, accountability to others, as well as imbalances of power, can be barriers to open, honest communications, which can potentially hinder the cultivation of critical friendship. Further, Swaffield (2007) notes the juxtaposition of "critical" and "friend" creates a tension between support and challenge resulting in a richness and "a successful marrying of unconditional support and unconditional critique" (MacBeath \& Jardine, 1998 as cited in Swaffield, 2007). An important component of the relationship is the deepening of friendship and associated strengthening of trust that facilitates the consideration of critique without defensiveness. Being a critical friend means providing different viewpoints, reframing, and reflecting. For example, Eisner (1991) states "Learning to see what we have learned not to notice remains one of the most critical and difficult tasks of educational connoisseurs. Everything else rests on it" (Swaffield, 2007, p.77).

\section{Self-Study}

\section{Methodology}

Positioned within the frameworks of teacher inquiry, action research, and reflective practice, self-study is a well-established research methodology used by teachers and teacher educators to create structures for ongoing professional development (Beck, Freese, \& Kosnik, 2004; LaBoskey, 2004; Bullough \& Pinnegar, 2001 Loughran, 2007; 2014; Loughran, Hamilton, LaBoskey, \& Russell, 2004). Self-study involves a systematic analysis of practice that acknowledges how the integration of self in research design can contribute to an understanding of pedagogy. Aimed at promoting the development of personal, constructivist, and collaborative professional communities of inquiry, self-study is an ideal methodology for inter-Faculty research concerned with both enhanced understanding of teaching and learning as well as the immediate improvement of practice (Macintyre Latta \& Buck, 2007; Ragoonaden \& Bullock, 2016). We have situated the conceptual framework of critical friendship within this rigorous methodology.

Data from our research notes, teaching notes and on-line journaling via Google Doc informed our practice. Regular readings from seminal researchers in self-study (Bullough \& Pinnegar, 2001; Hamilton, 2004; Kitchen, 2005; Kitchen \& Russell, 2012; Loughran et al., 2004; Samaras, 2011) and critical friendship (Costa \& Kallick, 1993; Baskerville \& Goldblatt, 2009; Ragoonaden \& Bullock, 2016; Schuck \& Russell, 2005; Swaffield, 2007) informed our written and oral reflections. Monthly meetings provided a time, a space, and a place for each of us to examine our practice (teaching), and praxis (reflections). Based on our negotiated 
understandings, we then moved through the act of searching, resolving, and clarifying emergent tensions (Bullough \& Pinnegar, 2001). We gave ourselves space for agreements and disagreements, examining and interrogating our lived experiences as teacher and nursing educators. Naming and then sharing these experiences with each other, and finding resonance in each other's positions, resulted in feelings of authenticity as well as a more nuanced selfunderstanding in practice. As our shared narratives evolved into "complicated conversations" (Pinar, 2004, pp.191-193), we became aware of nascent moral and ethical interrogations, which supported self-understandings and an increased awareness of the import of self in practice. We explored our own frames of reference and became more open to learning about ourselves, questioning previously held assumptions, and using our personal stories as texts for teaching one another (Bullough \& Pinnegar, 2001; Makaiau \& Freese, 2013; Ragoonaden, 2015).

\section{A Layered Approach to Critical Friendship}

The first iteration of a layered approach to critical friendship was between Lisa and Lindsay, colleagues in the School of Nursing (Ní Chróinín, O’Sullivan, \& Fletcher, 2016a). Sharing a similar teaching load, they met regularly to review weekly reflective journal entries and teaching notes. The weekly reflections were emergent and framed around Beck's (2001) five themes of caring in nursing education: presencing, sharing, supporting, competence, and positive impact and Noddings (2005) ethic of care.

In keeping with the model established by Ní Chróinín, O’Sullivan, and Fletcher (2016a; $2016 \mathrm{~b}$ ), the second iteration of a layered critical friendship involved a type of "meta-critical friend" (p. 8), occupying a third space in the triad and contributing another level of critical engagement. Karen, a colleague in the Faculty of Education, adopted this role. As a member of an International Self-Study Research Collective (Strong Makaiau, Ching-Sze Wang, Ragoonaden, \& Leng, 2016), Karen's previous experience provided solid parameters upon which to lay the foundations of this type of professional learning. Her role, similar to O' Sullivan's in Ní Chróinín et al. (2016a; 2016b) was to be a sounding board, identifying emergent issues, supporting and guiding through uncertain terrain and offering constructive criticism (Costa \& Kallick, 1993). This occurred during monthly meetings where the discussion flowed and included critical conversations, a review of progress, design of next steps and potential plans to disseminate findings. This process underscored the significance of peer interaction in supporting the conceptualization and implementation of evidence-based pedagogical practices for teacher educators and nursing educators.

Within this context, we, as critical friends would actively listen, comment, and journal about the reflective narratives of teaching experiences and the connections or lack of connections made with the content and/or students. Engaging with our thoughts and feelings about our teacher and nursing education practices and paying attention to our inner selves helped us to develop more consistent approaches by identifying principles relating to our respective practices. We recognized that reflective stances, which supported the development of trust, confidence and caring, were important processes and values that we adhered to despite our different contexts. This was reflective of a critical collaborative inquiry where the critical friend asks questions to understand the practice and to clarify the context of teaching and learning. We were also mindful of the foci on a transparent and systematic process required for self-study research (Pinnegar \& Hamilton, 2009; Samaras, 2011). Data collected from research notes, teaching 
notes, online journaling and meetings provided a solid foundation upon which to connect ideas, develop reflective stances, and determine inherent tensions and complexities of practice.

As we read our data, we searched for the manifestation of similar notions and views. Samaras (2011) refers to this as check coding seeking to establish similar or contrasting themes. Looking for patterns and recurring themes, we were able to identify emergent themes relating to relevant and relational pedagogy on theory and practice. During the course of ongoing multiple readings and meetings, these categories were related to the initial codes we identified early on during our first meetings. We used extracts from research notes, teaching notes and online journaling to identify and support the similarities and the differences of our experiences in education and in nursing. Summarizing the information coming from the initial and the ensuing codification, we were able to construct our writing by juxtaposing practice (techne) with the emergence of practical wisdom (phronesis) (Ragoonaden \& Bullock, 2016). Positioning this new knowledge as professional learning, the following narratives offer summative insights into our critical friend journey as we explored thematic considerations of reflection, trust, confidence, and caring.

\section{Results}

A qualitative analysis of our research notes, teaching notes, journaling, and meetings produced four identifiable themes: reflection, trust, confidence, and caring. These themes are representative of the choices/tensions that we struggled with, discussed, and tried to balance via our informed readings. They are also representative of our shared experiences as we embarked on mutual discourses of professional learning in education and in nursing.

\section{Reflection}

Karen began the process by writing about the challenges she anticipated working in an inter-disciplinary environment:

Being a meta critical friend with two Nursing colleagues is new to me.

I am looking forward to this process and hope that we are able to sustain this relationship. Time is such an issue on this campus-we all do so much. I hope that we are able to find common ground in which we can learn from one other and share in past and present experiences. No judgment, no biases, no assumptions. (Karen, Researcher Notes, September 2015)

Lisa's and Lindsay's initial comments were indicative of the process of reflecting and noticing how the passage of time can inform future practice:

Completing the CFiNe journals has forced me to write down my thoughts and perspectives about lectures, which are valuable, but also specific details about what I would keep and what I would change. I appreciate how incredibly useful this tool is for professional learning because it is not always possible to remember little changes that I thought would be important, several months later. (Lisa, Research Notes, September 20'2016)

Engaging in $\mathrm{CFiNe}$ has made me more reflective about my teaching practice. Our discussions have provided me with guidance on how to articulate my feelings about my 
role as a teacher, concrete perceptions about my performance and guidance for professional development. (Lindsay, Research Notes, October, 2016).

\section{Trust}

As the meetings progressed, we discussed the pivotal concept of trust as an important component of Critical Friendship in professional contexts:

I had approached several colleagues prior to teaching this course the first time and came away frustrated, unsure \& nervous..., it speaks to how important trust is ...(Lisa, Research Notes, September $12^{\text {th }} 2016$ )

I wish that I had more time to spend with my critical friend because I appreciate the input and trust her ideas and opinions on different teaching strategies to promote student engagement. Going forward, I want more structure in our interactions, meeting weekly to discuss ideas before and after classes. (Lindsay, Research Notes, September, 2016)

As I listened to Lisa \& Lindsay speak about their week, I noted the ease and the comfort that they had with each other. They trusted each other and me, as well. (Karen, Research Notes, October, 2016)

An interesting reflection from Lisa demonstrated how she became aware of Lindsay's trust in her judgment:

My critical friend taught one of my classes. We had discussed her expectations and my role in providing constructive feedback. After class, I was a bit hesitant at first, considering how to give her feedback, because I didn't want to sound too critical and not highlight enough of the positives. However, she was clear that she just wanted to know what I thought would improve her performance. That spoke of how powerful mutual trust is in critical friendship. She trusted that I would not disparage her work in any way and that my only goal was to provide my perspective on strategies to improve delivery. It was a refreshing and liberating experience to be able to focus solely on collaborating to improve the lecture (Lisa, Research Notes, March 14, 2017).

\section{Confidence}

As the semesters progressed, trust became anchored between all three of us; the data revealed that the levels of confidence in ourselves and the process was increasing:

Discussions with my critical friends allow me to learn about new teaching strategies to actively engage students, but from a perspective of understanding how strategies might be used in a specific context. Through collaborative discussions, I have gained confidence in using strategies that have not only been used successfully but are contextualized to my courses. This is a unique bonus! (Lisa, Teaching Notes, September 2016)

Debriefing with my critical friend in between teaching a first and second class on the same content increases my confidence. She helps to validate what I thought went well and what strategies might be used for subsequent classes. (Lindsay, Teaching Notes, September 2016) 
Despite initial concerns, I am surprised at how well this is working. Listening to Lisa \& Lindsay and then, making suggestions about teaching orientations, activities and/or assessment, I feel confident in the directions taken and know that they will only take what they need. I do not have all the answers and only make suggestions. (Karen, Research Notes, November 2016)

As an example of how her practice has changes, Lindsay describes the encouragement given by Lisa:

My critical friend encouraged me to provide feedback to guest speakers. I have to say that I did not want to do this. The guest speakers did not ask for feedback and I didn't really want to deliver the constructive (negative) feedback. CFiNe discussions increased my confidence in approaching future guest speakers about the importance of providing feedback to lecturers. (Lindsay, Research Notes, October 2016)

\section{Caring}

To care and the act of caring is a seminal concept found in both Education and Nursing. The following data demonstrate the importance of developing the attribute of caring including being the carer and being cared for:

My "new" approach demonstrated a determination to adopt a more caring perspective and ensure that students were engaged (which I usually am concerned with) and that students also have a voice. Genuinely seeking input from students and allowing discussions to unfold naturally based on what students come up with. (Lisa, Research Notes, September $12,2017)$

Lindsay writes about self-care and the decision to progress through her teaching:

These classes were challenging because I was quite ill - I feel that I had to discuss content/theory with the students my physical/emotional feelings would have greatly interfered with my ability to notice if the students were engaged or not. Feeling this way was really all about me and not about a student focus. (Lindsay, Teaching Notes, October 2016)

\section{Discussion}

The corpus of research notes, teaching notes, and online journaling indicated that reflection, trust, confidence, and caring were important considerations in the deliberations of our critical friendship. Dana and Yendol-Hoppey (2014) address the importance of self-generated inquiry into practice, stipulating that this type of engagement supports emergent reflection and the necessary confidence building to explore new pathways in pedagogy. The weekly discussions stemming from research notes and teaching notes tended to be framed around Beck's (2001) five themes of caring in nursing education: presencing, sharing, supporting, competence, and positive impact. In particular, both Lisa and Lindsay shared their reflections relating to the positive impact of being supported by a trusted colleague. Lindsay wrote about Lisa encouraging her to provide critical feedback to guest lecturers. Despite her nervousness, she was able, with support from her critical friend, to critically comment on the lecture. This is pertinent to Beck's (2001) concept of presencing, where one's self strives to enter the world of another, in this case, Lisa 
positioning herself in the guest lecturers sphere. An ethic of care (Noddings, 1999 2003; 2005; Tanner, 2016) featured in the research notes, teaching notes and online journaling.

We, as critical friends wrote and discussed the importance of trust and ensuing care: how to optimize practice and how to ensure transparency and open communication with one another. During this discussion, an important element that surfaced was the concept of judgment. We shared our negative experiences with colleagues who were judicious and dismissive of our practice and praxis. We recounted the feelings of worthlessness and the ensuing lack of confidence that emerged after these encounters. Within our inter-Faculty community of inquiry, there was no instance of discrimination or harsh criticism. Constructive critique, taking into consideration multiple perspectives in Education and Nursing, were always brought to the forefront of the discussion. Acknowledging different professional perspectives, we were socially, emotionally, and intellectually invested in our community of inquiry. This became an embodied teaching and learning experience (Dewey, 1933). Senge (1990) and Swaffield (2007) recognize the paradigm of critical friendship as a construct to elicit positive change with a focus on selfimprovement on practice. The interprofessional collaboration between Education and Nursing colleagues was sustainable and proffered a professional learning design that promoted interdisciplinary and collaborative thinking, which in turn impacted on practice. By their own accord, Lisa and Lindsay as nursing educators embarked on their reflective journeys and considered their practices in new ways. As a meta-critical friend, Karen from Education, guided and prodded their thinking, pushing into uncomfortable areas that called for exploration. For example, when prompted by Lisa and Lindsay, Karen provided alternative examples of collaborative assignments done in teacher education. This was often considered by Lisa and Lindsay and revised to fit their context in nursing education. West (2000) and Hill (2002) consider this process as scholarly inquiry based on a systematic process which reframes current practice by cultivating constructive critique. Of import in this relationship is the concept of trust. O'Neill (2002) speaks to the importance of calculative trust and practice trust. We, as three critical friends came together in a climate of calculative trust making a deliberate professionally mandated decision to participate in a community of inquiry. As the process evolved, shared discourses and narratives facilitated the development of a form of practice trust based on collaborative experiences. This process is representative of Eisner's (1991) premise that a critical friend needs to be a perceptive and receptive connoisseur who supports expertise in her partner.

Inter-Faculty critical friendship between Education and Nursing colleagues offered a paradigm in which to explore practice, praxis, and research. Lisa and Lindsay acknowledged that educators in health professions continue to predominantly employ traditional, teacher-centered methods of instruction that do not necessarily encourage the active and collaborative participation of students (Tanner, 2016). Karen noted that educational practitioners often model a Dewyan perspective where authentic, embodied learning is positioned. A community of inquiry populated by education and nursing faculty can provide parameters where interdisciplinary deliberations, despite differences, can inform best practice by creating non-judgemental and respectful environments (Lave \& Wenger, 1991).

Based on the above, the critical friendship established between colleagues in teacher education and nursing education demonstrated that the necessary conditions for a successful critical friendship resided in the development of trust, facilitated by a critical reflective stance leading to greater awareness and self-confidence in practice. To respond to the research objectives, this inquiry began by examining how a responsive collective made up university 
educators in interdisciplinary fields, seeking to improve practice embarked on a professional development initiative called critical friendship.

\section{Limitations}

It is important to note that Özek, Edgren, and Jandér (2012) undertook a comprehensive literature review of the terms critical friend and peer observation in order to learn about implementing the critical friend method in an academic library setting. This search indicated that a variety of definitions for critical friend exists. Within this multiplicity, they noted that negative results are rarely published. In our own work, we identified the lack of time in our academic schedules as impediments to our progression as critical friends. Institutional structures in Education and Nursing Education do not provide ample time for cultivating and nurturing interdisciplinary collaborative stances. In terms of establishing critical validity, this may be problematic in future iterations of this ongoing inquiry. However, of consideration is the fact that numerous authors refer to the process of critical friend as a supportive yet challenging relationship between professionals, encouraging and cultivating constructive critique and requiring knowledge of the context of the teaching environment (Costa \& Kallick, 1993; Baskerville \& Goldblatt, 2009; Hill, 2002; Ragoonaden \& Bullock, 2016; Schuck \& Russell, 2005; Senge, 1990; Swaffield 2007; West, 2000)

\section{Future Directions: Shaping the Mind for Practice}

Future directions for establishing critical friendship as a component of professional learning includes positing Sullivan and Rosin's (2008) agenda for higher education. By shaping the mind for practice, they propose that an interdisciplinary approach supported by practice and praxis provides a novel lens to the scholarship of teaching and learning. Campus-wide reflective communities of practice, situated into inquiry-based models, sustained with contributions from interdisciplinary colleagues, can provide spaces where pedagogical practices can be carefully planned, continuously revised, and where curriculum can be re-negotiated according to the plurality of contemporary society. In this progressive context, interdisciplinary Faculties, such as Education and Nursing, can spearhead campus-wide initiatives in developing and sustaining the mind for educational practice through the scholarship of teaching and learning (Boyer, 1990; Shulman, 2004).

\section{Conclusion}

Acknowledging the import of interdisciplinarity and its relationship to social understanding, this valuable initiative provided the impetus to change the inter-Faculty perceptions regarding the professional practice of teacher and nursing education. A relevant disposition that became known was acknowledging that the concept of critical is often equated with judgment and criticism. Since critique is not the objective of critical friendship, a sustainable, formalized process is required, which seeks to nurture the socio-emotional connections between the participants. We learned that critical friendships must be nurtured in a climate of trust, compassion and empathy, encouraging analysis, and integrity, and must culminate with an advocacy for success, all necessary conditions for the emergence of practical wisdom (Ragoonaden \& Bullock, 2016).

Within the context of qualitative research in the area of professional learning, collaborative critical friendship becomes a crucial element in the emergent process emphasizing a shared, grounded reflective approach that generates feedback and an awareness of a deeper 
comprehension of the experience. This research may contribute to the creation of sustainable professional learning models that engage university faculty in inquiry as a means of promoting shifts in practice (Macintyre Latta, Hanson, Ragoonaden, Briggs, \& Middleton, 2017). Within this context, critical friendship aligned with self-study research methodologies is presented as promising approach for achieving this goal (Pinnegar \& Hamilton, 2009 Loughran, 2007; 2014; Samaras, 2011). Designed to give structure to the ongoing professional development of university educators who work in a wide range of cultural contexts and educational settings, critical friendship can provide a forum where self-reflection, dialogue, professional, and personal growth, and learning about the inter-Faculty partnerships and connections can be nurtured and fostered. 


\section{References}

Baskerville, D., \& Goldblatt, H. (2009). Learning to be a critical friend: From professional indifference through challenge to unguarded conversations. Cambridge Journal of Education, 39(2), 205-221.

Beck, C. (2001). Caring within nursing education: A metasynthesis. Journal of Nursing Education, 40(3), 101-109.

Beck, C., Freese, A., \& Kosnik, C. (2004). The preservice practicum: Learning through selfstudy in a professional setting. In J. Loughran, M. L. Hamilton, V. K. LaBoskey, \& T. Russell, T. (Eds.), International handbook of self-study of teaching and teacher education practices. Dordrecht, NL: Kluwer.

Boyer, E. L. (1990). Scholarship reconsidered: Priorities of the professoriate. Princeton,NJ: The Carnegie Foundation for the Advancement of Teaching.

Bullough, R. V. Jr., \& Pinnegar, S. (2001). Guidelines for quality in autobiographical forms of self-study research. Educational Researcher, 30(3), 13-21. doi/10.3102/0013189X030003013

Cochran-Smith, M., \& Lytle, S. L. (2009) Inquiry as stance: Practitioner research for the next generation. New York, NY: Teachers College Press.

Coombs, C. P. (2001). Reflective practice, developing habits of mind (Doctoral dissertation) Retrieved from the National Library of Canada/ Bibliothèque nationale du Canada). http://www.collectionscanada.ca/obj/s4/f2/dsk3/ftp04/NQ58645.pdf

Costa, A. L., \& Kallick, B. (1993). Through the lens of a critical friend. Educational leadership, $51,49-49$.

Dana, N. F. \& Yendol-Hoppey, D. (2014) The reflective educator's guide to classroom research: Learning to teach and teaching to learn through practitioner inquiry, (3rd ed.). Thousand Oaks, California: Corwin Press.

Davies, E. (1995). Reflective practice: A focus for caring. Journal of Nursing Education, 34(4), $167-174$.

Dewey, J. (1933). The process and product of reflective activity: Psychological process and logical forms. In J. Boydston (Ed.), The later works of John Dewey (Vol. 8, pp. 171-186). Carbondale, IL: Southern Illinois University Press.

Dewey, J. (1938). Experience and education. New York, NY: Collier Books.

Doty, M. H. (2001). A qualitative examination of teaching portfolios as a means of transmitting science education values and promoting reflective practice in novice teachers. (Doctoral dissertation). Columbia University Teachers College, 2001. Dissertation Abstracts International, 62, 1780.

Eisner, E. W. (1991). The enlightened eye: Qualitative inquiry and the enhancement of educational practice. New York, NY. Macmillan. 
Ferry, N. M., \& Ross-Gordon, J. M. (1998). An inquiry into Schön's epistemology of practice: Exploring links between experience and reflective practice. Adult Education Quarterly, 48(2), 98-112.

Genor, M. A. (2002). Investigating the value of a preservice learning community: Promoting reflection in a teacher study group. (Doctoral dissertation). The University of WisconsinMadison, 2001. Dissertation Abstracts, International, 62, 13745.

Halldorsdottir, S. (1990). The essential structure of caring and uncaring encounter with a teacher. The perspective of the nursing student. In M. Leininger \& J. Watson (Eds), The caring imperative in education (pp. 95-108). New York: NLN Press.

Hamilton, M. L. (2004). Professional knowledge, teacher education and self-study. In J. Loughran, M. L. Hamilton, V. K. LaBoskey, \& T. Russell (Eds.), International handbook of self-study of teaching and teacher education practices (pp. 375-419). Dordrecht, NL: Kluwer.

Hill, G.W. (2002). Critical friendship. Brisbane, AU: Mottram D’Hill \& Associates.

Jaworski, B. (2006). Developmental research in mathematics teaching and learning: Developing learning communities based on inquiry and design. Proceedings of the 2006 annual meeting of the Canadian Mathematics Education Study Group. Calgary, Canada: University of Calgary.

Kitchen, J. (2005). Conveying respect and empathy: Becoming a relational teacher educator. Studying Teacher Education, 1(2), 195-207.

Kitchen, J., \& Russell, T. (Eds.). (2012). Canadian perspectives on the self-study of teacher education practices (Canadian Research in Teacher Education. A Polygraph Series. Vol. 2). Ottawa, ON: Canadian Association of Teacher Education (CATE)/Association canadienne de formation d'enseignants (ACFE).

LaBoskey, V. K. (2004). The methodology of self-study and its theoretical underpinnings. In J. J. Loughran, M. L. Hamilton, V. K. LaBoskey, \& T. Russell (Eds.), International handbook of self-study of teaching and teacher education practices (pp. 817-869). Dordrecht, NL: Kluwer.

Lave, J., \& Wenger, E. (1991). Situated learning: Legitimate peripheral participation. Cambridge, UK: Cambridge University Press.

Loughran, J. (2007). Researching teacher education practices: Responding to the challenges, demands, and expectations of self-study. Journal of Teacher Education, 58(1), 12-20.

Loughran, J. (2014). Professionally developing as a teacher educator. Journal of Teacher Education, 65(4), 271-283.

Loughran, J., Hamilton, M. L., LaBoskey, V. K., \& Russell, T. (Eds.). (2004). International handbook of self-study of teaching and teacher education practices. Dordrecht, NL: Kluwer. 
Lundberg, K. M. (2008). Promoting self-confidence in clinical nursing students. Nurse Educator, $33(2), 86-89$.

Macintyre Latta, M., \& Buck, G. (2007). Professional development risks and opportunities embodied within self-study. Studying Teacher Education, 3(2), 189-205.

Macintyre Latta, M., Hanson, K., Ragoonaden, K., Briggs, W., \& Middleton, T. (2017). Accessing the curricular play of critical and creative thinking. Canadian Journal of Education, 4(3), 1-28.

Makaiau A. S., \& Freese, A. R. (2013). A transformational journey: Exploring our multicultural identities through self-study. Studying Teacher Education, 9(2),141-151.

Makaiau, A. S., Leng, L. \& Fukui, S. (2015). Journaling and self-study in an international research collective. Studying Teacher Education, 11(1), 64-80.

Nelson, T. H., Slavit, D., Perkins, M., \& Hathorn, T. (2008). A culture of collaborative inquiry: Learning to develop and support professional learning communities. Teachers College Record, 110(6), 1269-1303.

Ní Chróinín, D., O'Sullivan, M., \& Fletcher, T. (2016a). Critical friendship and meta-critical friendship: Re-interrogating assumptions. In K. Ragoonaden \& S.M. Bullock (Eds.). Mindfulness and critical friendship: A new perspective on professional development for educators (pp. 77-90). Lanham, MD: Lexington Books.

Ní Chróinín, D., O'Sullivan, M., \& Fletcher, T. (2016b). A layered approach to critical friendship and its role in supporting pedagogical innovation in teacher education. Studying Teacher Education, 12(3), 302-319.

Noddings, N. (1999). Caring and competence. In G. Griffen (Ed.), The education of teachers (pp. 205-220). Chicago, IL: National Society of Education.

Noddings, N. (2003). Caring: A feminine approach to ethics and moral education, $\left(2^{\text {nd }}\right.$ ed.) Berkeley, CA: University of California Press.Noddings, N. (2005) Caring in education. The encyclopedia of informal education. Retrieved from www.infed.org/biblio/noddings_caring_in_education.htm.

O'Neill, O. (2002) A Question of Trust: The BBC Reith Lectures 2002. Cambridge: Cambridge University Press.

Özek, Y. H., Edgren, G., \& Jandér, K. (2012). Implementing the critical friend method for peer feedback among teaching librarians in an academic setting. Evidence Based Library and Information Practice, 7(4), 68-81.

Pinnegar, S., \& Hamilton, M. L. (2009). Self-study of practice as a genre of qualitative research: Theory, methodology, and practice (Vol. 8): Springer Netherlands

Pinar, W. F. (2004). What is Curriculum Theory? New York, NY: Routledge

Pithouse-Morgan, K., \& Samaras, A. P. (Eds.). (2015). Polyvocal professional learning through self-study research. Rotterdam, NL: Sense Publishers. 
Ragoonaden, K. (2015). Self-study of teacher education practices and critical pedagogy: The fifth moment in a teacher educator's journey. Studying Teacher Education 11(1), 81-95. http://www.tandfonline.com/doi/pdf/10.1080/17425964.2015.1018886

Ragoonaden, K., \& Bullock, S. (2016). Critical friends: The practiced wisdom of professional development. In K. Ragoonaden \& S. Bullock (Eds.), Mindfulness and critical friendship: A new perspective on professional development for educators (pp.13-32). Lanham, MD: Lexington Books.

Samaras, A. P. (2011). Self-study teacher research: Improving your practice through collaborative inquiry. Thousand Oaks, CA: Sage.

Schön, D. (1983). The reflective practitioner: How professionals think in action. San Francisco, CA: Jossey-Bass.

Schuck, S., \& Russell, T. (2005). Self-study, critical friendship, and the complexities of teacher education. Studying Teacher Education, 1(2), 107-121.

Senge, P. (1990). The fifth discipline: The art and practice of the learning organisation. New York, NY: Doubleday.

Shulman, L. S. (2004). The wisdom of practice: Essays on teaching, learning, and learning to teach. San Francisco, CA: Jossey-Bass.

Strong Makaiau, A., Ching-Sze Wang, J., Ragoonaden, K., \& Leng, L. (2016). Empowering global P4C research and practice through self-study: The philosophy for children in Hawaii international journaling and self-study project. In M. Gregory, J. Hayes, \& K. Murris (Eds.), The Routledge international handbook of philosophy for children, Section IX - Research directions and methods in philosophy for children (pp.227-235). New York, NY: Routledge.

Sullivan, W. M., \& Rosin, M. (2008). A new agenda for higher education: Shaping a life of the mind for practice. San Francisco, CA: Jossey-Bass.

Swaffield, S. (2007) Light touch critical friendship. Improving Schools, 10(3), 205-219.

Tanner, C.A. (2016). Thinking like a nurse: A research-based model of clinical judgment in nursing. Journal of Nursing Education, 45(6), 204-211.

West, H. (2000). Supporting school improvement: Observation on the inside, reflection on the outside. School Leadership and Management, 20(1), 43-60. 